\title{
Effects of Pumpkin (Cucurbita moschata Duch.) Leaf Ethanolic Extracts on Lipid Oxidation and Microbial Activity in Refrigerated Raw Ground Pork
}

\author{
Ju- Hui Choe', Hack-Youn Kim², Yun-Sang Choi ${ }^{2}$, Doo-Jeong Han¹, Ji-Hun Choi', \\ Yong-Jae $\mathrm{Kim}^{1}$, and Cheon-Jei Kim ${ }^{1,2 *}$ \\ ${ }^{1}$ Department of Food Science and Biotechnology of Animal Resources, Konkuk University, Seoul 143-701, Korea \\ ${ }^{2}$ Research Institute for Meat Science and Culture, Konkuk University, Seoul 143-701, Korea
}

\begin{abstract}
This study was conducted to evaluate the antioxidant effects of pumpkin leaf extracted using a $50 \%$ ethanol on ground pork during storage. The pumpkin leaf extracts were added at concentrations of 0.05 (PE-0.05), 0.1 (PE-0.1), and 0.2\% (PE0.2 ) to ground pork, and $0.05 \%$ of ascorbic acid (As-0.05) was added as a control. Each sample was collected after 1, 4, 7, and $10 \mathrm{~d}$ of storage and the $\mathrm{pH}$, total viable counts (TVC), conjugated dienes (CD), free fatty acids (FFA), and thiobarbituric reaction substance (TBARS) values were measured. The $\mathrm{pH}$ of the pork samples decreased until day 7 , and then increased thereafter, except for the control and PE- 0.05 sample. Lower CIE $a^{*}$ values were observed for pork samples containing PE relative to As- 0.05 at increasing storage time $(p<0.05)$. The addition of PE decreased the TVC, CD, FFA and TBARS values levels in the ground pork when compared to the control during $10 \mathrm{~d}$ of storage. These results indicate that PE can produce notable effects on meat products, such as inhibiting lipid oxidation and discoloration.
\end{abstract}

Key words: pumpkin leaf, lipid oxidation stability, shelf-life stability, ground pork

\section{Introduction}

Ground pork is widely used due to convenience in the food industry around the world. Ground pork is also used as an ingredient Tteok-galbi, which is a traditional Korean food, and in hamburger patties. However, grinding accelerates lipid oxidation through oxidative reactions. Hydroperoxides, which are the primary oxidation products, are formed and then decompose into low molecular weight compounds such as ketones, aldehydes, and hydroxides during lipid oxidation of meat (St. Angelo, 1996). These lipid oxidation products result in unacceptable color, reduced shelf-life, unacceptable odors, and sensory changes (Ladikos and Lougovois, 1990).

Autoxidation in meat can be effectively inhibited using synthetic antioxidants such as butylated hydroxyanisole (BHA), butylated hydroxytoluene (BHT), and propyl gallate (PG) (Barlow, 1990). However, due to growing concerns about food safety, the use of synthetic antioxidants has decreased because of their potential genotoxicity and carcinogenicity (Gharavi et al., 2007). Consumer interest

*Corresponding author: Cheon-Jei Kim, Department of Food Science and Biotechnology of Animal Resources, Konkuk University, Seoul 143-701, Korea. Tel: 82-2-450-3684, Fax: 82-2-444-6695, E-mail: kimcj@konkuk.ac.kr in safety has resulted in an increased utilization of natural antioxidants in meat products (Hinneburg et al., 2006). The addition of plant materials can provide minerals, vitamins, phenolic compounds, and flavonoid compounds to meet these demands.

Pumpkin (Cucurbita moschata Duch.) is cultivated all over the world and belongs to the family Cucurbitaceae. Pumpkin leaf has been widely used as a major ingredient in rice wraps, soups, and fermented foods. Traditionally, pumpkin leaf has been used to treat health problems such as night blindness, burns, and xerotic keratitis due to its pharmacological activity (Cha, 2009). Pumpkin leaf contains abundant antioxidant compounds including carotenoids and tocopherols (Stevenson et al., 2007), phenolic compounds, and trace elements (Glew et al., 2006). Several studies have examined the antioxidant activities of pumpkin (Kwon et al., 2007), pumpkin leaf (Cha, 2009), pumpkin seeds (Xanthopoulou et al., 2009), pumpkin oil (Fruhwirth et al., 2003), and pumpkin seed flour (Parry et al., 2008).

In this study, the antioxidant activity of a pumpkin leaf ethanolic extract was investigated in ground pork meat during chilled storage, as measured by instrumental color, total viable counts (TVC), conjugated dienes (CD), free fatty acids (FFA), and thiobarbituric acid reaction substance (TBARS) values and compared with ascorbic acid. 
In addition, the proximate and $\mathrm{pH}$ values of the ground pork meat containing pumpkin leaf ethanolic extracts were evaluated during $10 \mathrm{~d}$ of storage.

\section{Materials and Methods}

\section{Preparation of pumpkin (Cucurbita moschata Duch.) leaf extracts}

The pumpkin leaves were washed and cut to separate the leaves and stems. The leaves were cut into small pieces, dried in a hot air dryer (Enex-Co-600, Enex, Korea) at $50^{\circ} \mathrm{C}$ for $12 \mathrm{~h}$, and powdered (35 mesh). The dried pumpkin leaf powder $(10 \mathrm{~g})$ was extracted with 200 $\mathrm{mL}$ of $50 \%$ ethanol overnight in a shaker (VS-8480, Vison Scientific, Korea) at room temperature. The extract was filtered through Whatman No. 1 filter paper and the solvent was removed using a vacuum evaporator (CCA1110 , Rikakikai, Japan) at $45^{\circ} \mathrm{C}$. After evaporation of ethanol, the pumpkin leaves ethanolic extracts were dissolved in $50 \%$ ethanol $(5 \%, \mathrm{v} / \mathrm{w})$.

\section{Preparation of meat samples}

Fresh pork hams and back fats were purchased from a pilot plant at Konkuk University, Korea, $48 \mathrm{~h}$ postmortem. All subcutaneous and intramuscular fat and visible connective tissues were removed from the fresh ham muscles.

The ground meat samples were produced using the following formulation: $73.5 \%$ lean pork meat, $20 \%$ pork back fat, $5 \%$ Ice, and $1.5 \%$ salt. The lean pork meat and pork back fat were ground through a $3 \mathrm{~mm}$ grinding plate and then the ice and salt were added. Ethanol extracts of pumpkin leaf (CIE L*: 9.02, CIE a*: 0.59, and CIE b*: 4.96) were added at a final concentration of $50 \%(\mathrm{w} / \mathrm{w})$ according to the following formulation: Control (without antioxidant); PE-0.05 (with $0.05 \%$ pumpkin leaf ethanolic extract); PE-0.1 (with $0.1 \%$ pumpkin leaf ethanolic extract); PE- 0.2 (with $0.2 \%$ pumpkin leaf ethanolic extract); and As- 0.05 (with $0.05 \%$ ascorbic acid). These percentages were based on the formula weight of the ground meat samples without the antioxidant extract. Samples were hand mixed for $5 \mathrm{~min}$. The mixed meat was then anaerobically packed in PE/nylon film bags, spread to a thickness of $2.5 \mathrm{~cm}$ and, stored at $4 \pm 1^{\circ} \mathrm{C}$ for $10 \mathrm{~d}$.

\section{Proximate composition}

The proximate properties of the samples were determined using standard AOAC (2000) methods. The mois- ture content was determined based on the weight loss after $12 \mathrm{~h}$ of drying at $105^{\circ} \mathrm{C}$ in a drying oven (SW-90D, Sang Woo Scienctific Co., Korea). The fat content was determined using the Sohxlet method with a solvent extraction system (Soxtec $^{\circledR}$ Avanti 2050 Auto System, Foss Tecator AB, Sweden). The protein content was determined using the Kjeldahl method with an automatic kjeldahl nitrogen analyzer (Kjeltec ${ }^{\circledR} 2300$ Analyzer Unit, Foss Analytical AB, Sweden) and the ash content was determined according to the AOAC (2000) method.

\section{pH values}

The $\mathrm{pH}$ values of the samples were measured using a pH meter (Model 340, Mettler-Toledo GmbH, Switzerland). The $\mathrm{pH}$ of the raw ground pork was measured after blending $5 \mathrm{~g}$ of sample with $20 \mathrm{~mL}$ of distilled water for $60 \mathrm{~s}$ in a homogenizer (Ultra-Turrax SK15, Janke \& Kunkel, Germany).

\section{Microbiological analysis}

A $5 \mathrm{~g}$ aliquot of each sample was aseptically transferred into a sterile stomacher bag at each respective sampling interval and $45 \mathrm{~mL}$ of sterile distilled water was added. The sample was then evenly mixed in the stomacher (Masticator-Paddle-Blender, IUL Instrument, Spain) for 2 min at normal speed and aliquots were plated out directly at a 1:10 dilution in sterile distilled water. After serially diluting each sample in sterile distilled water, $0.1 \mathrm{~mL}$ were separately plated onto plates. The total bacterial count was determined on plate count agar (PCA, Difco, USA) at $35^{\circ} \mathrm{C}$ for $48 \mathrm{~h}$. Total viable counts (TVC) were counted and expressed as Log CFU/g pork meat.

\section{Instrumental color measurement}

The instrumental color analyses of the raw pork patties were conducted as follows. The color measurements were acquired using a colorimeter (Chroma meter CR-210, Minolta, Japan; illuminate $\mathrm{C}$, calibrated with a white standard plate $\mathrm{CIE} \mathrm{L}^{*}=97.83, \mathrm{CIE} \mathrm{a}{ }^{*}=-0.43, \mathrm{CIE} \mathrm{b}^{*}=$ +1.98 ), which consisted an $8 \mathrm{~mm}$ diameter measuring area and a $50 \mathrm{~mm}$ diameter illumination area. The color values (CIE L ${ }^{*}, a^{*}$, and $\left.b^{*}\right)$ were measured on the sample surfaces and data were collected in triplicate for each sample.

\section{Thiobarbituric acid reaction substance (TBARS) values}

Lipid oxidation was assessed in triplicate using the 2thiobarbituric acid (TBA) assay described by Tarladgis et 
al. (1960) with minor modifications. Fifty milliliters of distilled water was added to $10 \mathrm{~g}$ of sample prior to homogenizing with a homogenizer (AM-7, Nihonseiki Kaisha Ltd., Japan) at 10,000 rpm for $2 \mathrm{~min}$. The cup used for blending was washed with an additional $47.5 \mathrm{~mL}$ of distilled water, which was added to the same distillation flask containing $2.5 \mathrm{~mL}$ of $4 \mathrm{~N} \mathrm{HCl}$ and a few drops of an antifoam agent, silicone o/w (KMK-73, Shin-Etsu Silicone Co., Ltd., Korea). The mixture was distilled and $50 \mathrm{~mL}$ distillate was collected. Five $\mathrm{mL}$ of $0.02 \mathrm{M} 2-$ thiobarbituric acid in 90\% acetic acid (TBA reagent) was added to a vial containing $5 \mathrm{~mL}$ of the distillate and mixed well. The vials were capped and heated in a boiling water bath for $30 \mathrm{~min}$ to develop the chromogen and cooled to room temperature. The absorbance was measured at $538 \mathrm{~nm}$, against a blank prepared with distilled water $(5 \mathrm{~mL})$ and TBA-reagent $(5 \mathrm{~mL})$, using a UV/VIS spectrophotometer (Libra S22, Biochrom Ltd., England). TBARS values were calculated by multiplying the absorbance by $73 \%$, which was the recovery of the standard from meat, resulting in a $\mathrm{K}$ value of 7.8. The TBA values were calculated as $\mathrm{mg} \mathrm{MDA} / \mathrm{kg}$ sample.

TBA (malonaldehyde $\mathrm{mg} /$ sample $\mathrm{kg}$ ) $=$ OD value $\times 7.8$

\section{Conjugated dienes (CD) and free fatty acids (FFA)}

Lipid extraction was conducted according to the method described by Folch (Folch et al., 1957) using a chloroform:methanol solvent system (2:1). The lipid extracts were evaporated and concentrated in a rotary evaporator (Rotary evaporator N-1000, Eyela, Japan). The extracted lipids were placed then analyzed by $\mathrm{CD}$ and FFA. The CD concentrations were determined as described by Prasetyo et al. (2008). Fifteen mg of extracted lipid sample was placed into a $25 \mathrm{~mL}$ volumetric flask and massed up with isooctane. The samples were mixed and the absorbance was read at $234 \mathrm{~nm}$ against a blank of isooctane using a UV/VIS spectrophotometer (Libra S22, Biochrom Ltd., England). The CD concentration was calculated using a molar extinction coefficient of 25,200 $\mathrm{M}^{-}$

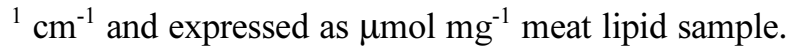

The free fatty acids (FFA) values of the extracted lipids were determined by AOCS (1987), and calculated as follows: $\mathrm{FFA}(\%)=(\mathrm{S}-\mathrm{B}) \times \mathrm{M}_{0} \times \mathrm{N} \times \mathrm{F} / \mathrm{W} \quad[\mathrm{S}=$ titration amount of sample; $\mathrm{B}=$ titration amount of blank; $\mathrm{M}_{0}=$ molecular weight of $\mathrm{KOH}$; F=titer of $0.01 \mathrm{~N} \mathrm{KOH}$; $\mathrm{N}=$ normality of $\mathrm{KOH}$; $\mathrm{W}=$ sample weight $(\mathrm{g})]$.
Analysis of variance was performed on all the variables measured using the General Linear Model (GLM) procedure of the SAS statistical package (SAS Institute, Inc., 2008). Duncan's multiple range test $(p<0.05)$ was used to determine the differences between treatment means.

\section{Results and Discussion}

\section{Proximate composition}

The addition of PE did not have an effect on the proximate composition of the ground pork (Table 1). The moisture content of ground pork samples ranged from 63.35-63.78\%. No significant differences were observed in moisture, protein, fat and ash content among the treatments.

\section{pH evaluations}

The $\mathrm{pH}$ values of the ground pork samples containing ethanolic pumpkin leaf extract ranged from 5.87 to 6.00 after $10 \mathrm{~d}$ of storage (Table 2). In addition, the $\mathrm{pH}$ increased $(p<0.05)$ with an increase in the pumpkin leaf extract concentration. The $\mathrm{pH}$ of all treatments decreased up to $7 \mathrm{~d}$ of storage, except for PE1. After $7 \mathrm{~d}$, the $\mathrm{pH}$ increased $(p<0.05)$. A similar study reported that $\mathrm{pH}$ values of ground pork containing garlic extracts decreased during the first $4 \mathrm{~d}$ of chilled storage, and significantly increased $(p<0.05)$ thereafter (Byun et al., 2001). Also, $\mathrm{pH}$ changes were observed in pork patties containing aloe vera, fenugreek, mustard, and rosemary extracts (Mc Carthy et al., 2001).

\section{Total viable counts (TVC)}

The TVC ranged from $2.45 \mathrm{Log} \mathrm{CFU} / \mathrm{g}$ to $4.65 \mathrm{Log}$ $\mathrm{CFU} / \mathrm{g}$ for the ground pork samples containing PE during

Table 1. Proximate composition of ground pork meat added ethanolic pumpkin leaf extracts (PE)

\begin{tabular}{lcccc}
\hline \hline \multirow{2}{*}{ Treatment $^{1)}$} & \multicolumn{4}{c}{ Proximate composition (\%) } \\
\cline { 2 - 5 } & Moisture & Protein & Fat & Ash \\
\hline Control & $63.51 \pm 0.24$ & $15.90 \pm 0.36$ & $17.49 \pm 0.35$ & $2.06 \pm 0.07$ \\
PE-0.05 & $63.64 \pm 0.15$ & $16.37 \pm 0.23$ & $17.42 \pm 0.33$ & $2.13 \pm 0.10$ \\
PE-0.1 & $63.43 \pm 0.23$ & $15.90 \pm 0.35$ & $17.73 \pm 0.51$ & $2.24 \pm 0.15$ \\
PE-0.2 & $63.78 \pm 0.40$ & $16.51 \pm 0.40$ & $17.26 \pm 0.33$ & $2.07 \pm 0.08$ \\
As-0.05 & $63.35 \pm 0.14$ & $16.36 \pm 0.27$ & $17.69 \pm 0.28$ & $1.95 \pm 0.14$
\end{tabular}

All values are mean $\pm \mathrm{SD}$ of three replicates.

${ }^{1)}$ Control, minced pork without antioxidant powder; PE-0.05, minced pork meat with $0.05 \%$ pumpkin leaf extracts; PE- 0.1 , minced pork meat with $0.1 \%$ pumpkin leaf extracts; PE- 0.2 , minced pork meat with $0.2 \%$ pumpkin leaf extracts; As- 0.05 , minced pork meat with $0.05 \%$ ascorbic acid

\section{Statistical analysis}


Table 2. Change in pH values of ground pork meat added ethanolic pumpkin leaf extracts (PE) during storage days

\begin{tabular}{lllll}
\hline \hline \multirow{2}{*}{ Treatment $^{1)}$} & \multicolumn{4}{c}{ Storage periods (d) } \\
\cline { 2 - 5 } & \multicolumn{1}{c}{1} & \multicolumn{1}{c}{4} & 7 & 10 \\
\hline Control & $5.87 \pm 0.09^{\mathrm{Cb}}$ & $5.90 \pm 0.05^{\mathrm{Ba}}$ & $5.93 \pm 0.06^{\mathrm{Aa}}$ & $5.87 \pm 0.09^{\mathrm{Cb}}$ \\
PE- 0.05 & $5.89 \pm 0.09^{\mathrm{C}}$ & $5.91 \pm 0.10^{\mathrm{B}}$ & $5.88 \pm 0.07^{\mathrm{C}}$ & $5.88 \pm 0.05^{\mathrm{BC}}$ \\
PE-0.1 & $5.88 \pm 0.06^{\mathrm{Cb}}$ & $5.92 \pm 0.07^{\mathrm{Ba}}$ & $5.88 \pm 0.07^{\mathrm{Cb}}$ & $5.90 \pm 0.03^{\mathrm{Bab}}$ \\
PE-0.2 & $5.94 \pm 0.08^{\mathrm{Ba}}$ & $5.93 \pm 0.04^{\mathrm{ABa}}$ & $5.91 \pm 0.08^{\mathrm{Bb}}$ & $5.92 \pm 0.05^{\mathrm{Bab}}$ \\
As-0.05 & $6.00 \pm 0.06^{\mathrm{Aa}}$ & $5.96 \pm 0.09^{\mathrm{Ab}}$ & $5.93 \pm 0.03^{\mathrm{Ac}}$ & $5.96 \pm 0.08^{\mathrm{Ab}}$ \\
\hline
\end{tabular}

All values are mean $\pm \mathrm{SD}$ of three replicates.

${ }^{A-C}$ Means within columns with different superscript letters are significantly different $(p<0.05)$.

${ }^{\mathrm{a}-\mathrm{c}}$ Means within rows with different superscript letters are significantly different $(p<0.05)$.

${ }^{1)}$ Control, minced pork without antioxidant powder; PE-0.05, minced pork meat with $0.05 \%$ pumpkin leaf extracts; PE-0.1, minced pork meat with $0.1 \%$ pumpkin leaf extracts; PE- 0.2 , minced pork meat with $0.2 \%$ pumpkin leaf extracts; As- 0.05 , minced pork meat with $0.05 \%$ ascorbic acid

$10 \mathrm{~d}$ of storage (Table 3). Generally, total viable counts above $7 \mathrm{Log} \mathrm{CFU} / \mathrm{g}$ can result in visible meat spoilage during aerobically refrigerated storage (Insausti et al., 2001). The TVC of the control increased to about $2 \log$ $\mathrm{CFU} / \mathrm{g}$ over the $10 \mathrm{~d}$ of storage. The TVC increased, between approximately 1.3 and $1.5 \mathrm{Log} \mathrm{CFU} / \mathrm{g}$, up to day 10 in the samples containing PE. The TVC was inhibited most by the PE- 0.2 treatment $(0.8 \mathrm{Log}$ CFU/g). Although PE was added to the pork samples, TVC inhibition may not have been affected by $\mathrm{pH}$, which clearly did not increase in the samples containing PE during the storage

Table 3. Total aerobic bacterial counts $(\log 10 \mathrm{CFU} / \mathrm{g})$ of ground pork meat added ethanolic pumpkin leaf extracts (PE) during storage days

\begin{tabular}{lcccc}
\hline \hline \multirow{2}{*}{ Treatment $^{1)}$} & \multicolumn{4}{c}{ Storage periods (d) } \\
\cline { 2 - 5 } & 1 & 4 & 7 & 10 \\
\hline Control & $2.76 \pm 0.05^{\mathrm{Ad}}$ & $3.11 \pm 0.03^{\mathrm{Ac}}$ & $3.95 \pm 0.04^{\mathrm{Ab}}$ & $4.65 \pm 0.05^{\mathrm{Aa}}$ \\
PE-0.05 & $2.58 \pm 0.03^{\mathrm{Bd}}$ & $2.83 \pm 0.04^{\mathrm{Dc}}$ & $3.65 \pm 0.06^{\mathrm{Cb}}$ & $4.02 \pm 0.01^{\mathrm{Ca}}$ \\
PE-0.1 & $2.45 \pm 0.02^{\mathrm{Dd}}$ & $2.94 \pm 0.01^{\mathrm{Cc}}$ & $3.49 \pm 0.04^{\mathrm{Db}}$ & $3.94 \pm 0.03^{\mathrm{Da}}$ \\
PE-0.2 & $2.51 \pm 0.03^{\mathrm{Cd}}$ & $2.67 \pm 0.06^{\mathrm{Ec}}$ & $3.38 \pm 0.03^{\mathrm{Eb}}$ & $3.87 \pm 0.02^{\mathrm{Ea}}$ \\
As-0.05 & $2.52 \pm 0.03^{\mathrm{Cd}}$ & $2.99 \pm 0.01^{\mathrm{Bc}}$ & $3.75 \pm 0.06^{\mathrm{Bb}}$ & $4.35 \pm 0.10^{\mathrm{Ba}}$ \\
\hline
\end{tabular}

All values are mean $\pm \mathrm{SD}$ of three replicates.

${ }^{A-E}$ Means within columns with different superscript letters are significantly different $(p<0.05)$.

${ }^{\mathrm{a}-\mathrm{d}}$ Means within rows with different superscript letters are significantly different $(p<0.05)$.

${ }^{1)}$ Control, minced pork without antioxidant powder; PE-0.05, minced pork meat with $0.05 \%$ pumpkin leaf extracts; PE-0.1, minced pork meat with $0.1 \%$ pumpkin leaf extracts; PE- 0.2 , minced pork meat with $0.2 \%$ pumpkin leaf extracts; As- 0.05 , minced pork meat with $0.05 \%$ ascorbic acid time. Decreases in TVC appeared to be an effect of PE.

\section{Instrumental color evaluation}

Discoloration in meat is interrelated with lipid oxidation and metmyoglobin production though the action of free radicals (O'Grady et al., 2001). The redness of meat is important to consumer acceptability. In all samples, $\mathrm{CIE} \mathrm{L}^{*}$ values significantly increased $(p<0.05)$ and CIE a ${ }^{*}$ values decreased $(p<0.05)$ over $10 \mathrm{~d}$ of storage (Table 4$)$. Increases in the PE concentration resulted in darker raw ground pork relative to the control during the entire storage period. The ground pork samples with PE had lower CIE a* values than the control. However, higher CIE a ${ }^{*}$ values were observed on day 4 for PE-0.1, PE-0.2, and As-0.05 samples as compared to day 1. Also, changes in redness were lowest in PE-0.1, and similar changes in values were observed for As- 0.05 , which can prevent discoloration with increasing storage time. Similar effects were observed in raw patties containing green tea ethanolic extract (Jo et al., 2003). The changes in redness were lower for samples containing PE, which this result indicates that $\mathrm{PE}$ is an effective agent for color stability. The addition of PE resulted in increased CIE $b^{*}$ values during the entire storage period, which may have been due to the deep green color of the PE.

\section{Conjugated dienes (CD) and Free fatty acids (FFA)}

Lipid oxidation in meat can result in quality deterioration and decreases in sensory and nutritional factors (Juntachote et al., 2007). Unsaturated lipids that have nonconjugated double bonds transform into conjugated dienes after peroxides are formed during lipid oxidation. Hydroperoxides hardly decompose during the early stage of lipid oxidation and decompose into secondary products at the later stage (Kulas and Ackman, 2001). Lipid oxidation can be measured based on the $\mathrm{CD}$ concentrations. The effects of $\mathrm{PE}$ on $\mathrm{CD}$ during storage are presented in Fig. 1. In the control, CD significantly increased until day 4 , and then significantly decreased until day 10 . Samples containing PE had increased concentrations of CD during storage from day 1 to day 7 , which concentrations significantly decreased at longer storage times $(p<0.05)$. This result may be due to decomposition into secondary products of conjugated diene hydroperoxides after peaked CD formation (Juntachote et al., 2007). Peña-Ramos and Xiong (2003) found that conjugated dienes in cooked pork patties made with hydrolyzed protein isolate (WPI) and soy protein isolate (SPI) increased until day 1 , and then decreased after day 1 , except for the control. The 
Table 4. Change in color stability of ground pork meat added ethanolic pumpkin leaf extracts (PE) during storage days

\begin{tabular}{clcccc}
\hline \hline & & \multicolumn{4}{c}{ Storage periods (d) } \\
\cline { 3 - 6 } & & 1 & 4 & 7 & 10 \\
\hline & Control & $57.44 \pm 0.70^{\mathrm{Cb}}$ & $55.65 \pm 0.97^{\mathrm{Cc}}$ & $58.73 \pm 0.57^{\mathrm{Bb}}$ & $61.76 \pm 0.93^{\mathrm{Aa}}$ \\
CIE L $^{*}$ & PE-0.05 & $60.74 \pm 0.96^{\mathrm{Aa}}$ & $61.06 \pm 1.08^{\mathrm{Ba}}$ & $57.81 \pm 1.35^{\mathrm{Bb}}$ & $60.95 \pm 1.05^{\mathrm{Ba}}$ \\
& PE-0.1 & $60.50 \pm 0.66^{\mathrm{ABa}}$ & $56.25 \pm 0.73^{\mathrm{Cb}}$ & $52.71 \pm 0.59^{\mathrm{Cc}}$ & $60.05 \pm 0.89^{\mathrm{Ca}}$ \\
& PE-0.2 & $55.97 \pm 0.64^{\mathrm{Db}}$ & $56.86 \pm 1.03^{\mathrm{Cb}}$ & $51.90 \pm 1.30^{\mathrm{Dc}}$ & $60.03 \pm 1.28^{\mathrm{Ca}}$ \\
& As-0.05 & $59.65 \pm 0.61^{\mathrm{Bd}}$ & $63.67 \pm 1.16^{\mathrm{Aa}}$ & $61.36 \pm 0.80^{\mathrm{Ac}}$ & $61.24 \pm 0.96^{\mathrm{ABbc}}$ \\
\hline & Control & $18.38 \pm 0.79^{\mathrm{Aa}}$ & $17.44 \pm 0.79^{\mathrm{ABb}}$ & $11.92 \pm 0.99^{\mathrm{Bc}}$ & $9.10 \pm 0.41^{\mathrm{Cd}}$ \\
CIE a $^{*}$ & PE-0.05 & $17.19 \pm 0.92^{\mathrm{Ba}}$ & $14.97 \pm 0.99^{\mathrm{Cb}}$ & $11.69 \pm 0.96^{\mathrm{Bc}}$ & $8.89 \pm 0.79^{\mathrm{Cd}}$ \\
& PE-0.1 & $14.96 \pm 0.59^{\mathrm{Cb}}$ & $18.02 \pm 0.72^{\mathrm{Aa}}$ & $12.55 \pm 0.91^{\mathrm{Bc}}$ & $9.05 \pm 0.96^{\mathrm{Cd}}$ \\
& PE-0.2 & $13.03 \pm 1.16^{\mathrm{Db}}$ & $16.74 \pm 0.88^{\mathrm{Ba}}$ & $10.63 \pm 0.74^{\mathrm{Cc}}$ & $6.14 \pm 0.57^{\mathrm{Dd}}$ \\
& As-0.05 & $15.59 \pm 0.94^{\mathrm{Cb}}$ & $16.68 \pm 0.98^{\mathrm{Ba}}$ & $15.16 \pm 0.97^{\mathrm{Ab}}$ & $11.13 \pm 0.90^{\mathrm{Ac}}$ \\
\hline & Control & $15.29 \pm 0.95^{\mathrm{Ba}}$ & $14.51 \pm 0.83^{\mathrm{Ca}}$ & $11.96 \pm 0.86^{\mathrm{Db}}$ & $15.15 \pm 0.75^{\mathrm{Ba}}$ \\
CIE b $^{*}$ & PE-0.05 & $16.18 \pm 0.94^{\mathrm{Aa}}$ & $16.61 \pm 1.12^{\mathrm{Ba}}$ & $13.15 \pm 0.99^{\mathrm{Cc}}$ & $15.02 \pm 1.47^{\mathrm{Bb}}$ \\
& PE-0.1 & $15.76 \pm 0.84^{\mathrm{ABb}}$ & $18.87 \pm 0.95^{\mathrm{Aa}}$ & $13.84 \pm 0.41^{\mathrm{BCc}}$ & $15.22 \pm 0.88^{\mathrm{Bb}}$ \\
& PE-0.2 & $15.59 \pm 0.94^{\mathrm{ABc}}$ & $19.67 \pm 0.81^{\mathrm{Aa}}$ & $15.98 \pm 0.83^{\mathrm{Abc}}$ & $16.81 \pm 0.97^{\mathrm{Ab}}$ \\
& As-0.05 & $14.20 \pm 0.69^{\mathrm{Cb}}$ & $17.43 \pm 0.94^{\mathrm{Ba}}$ & $14.39 \pm 0.73^{\mathrm{Bb}}$ & $12.86 \pm 0.96^{\mathrm{Cc}}$ \\
\hline
\end{tabular}

All values are mean $\pm \mathrm{SD}$ of three replicates.

${ }^{\text {A-D }}$ Means within columns with different superscript letters are significantly different $(p<0.05)$.

${ }^{\mathrm{a}-\mathrm{d}}$ Means within rows with different superscript letters are significantly different $(p<0.05)$.

${ }^{1)}$ Control, minced pork without antioxidant powder; PE- 0.05 , minced pork meat with $0.05 \%$ pumpkin leaf extracts; PE-0.1, minced pork meat with $0.1 \%$ pumpkin leaf extracts; PE- 0.2 , minced pork meat with $0.2 \%$ pumpkin leaf extracts; As- 0.05 , minced pork meat with $0.05 \%$ ascorbic acid

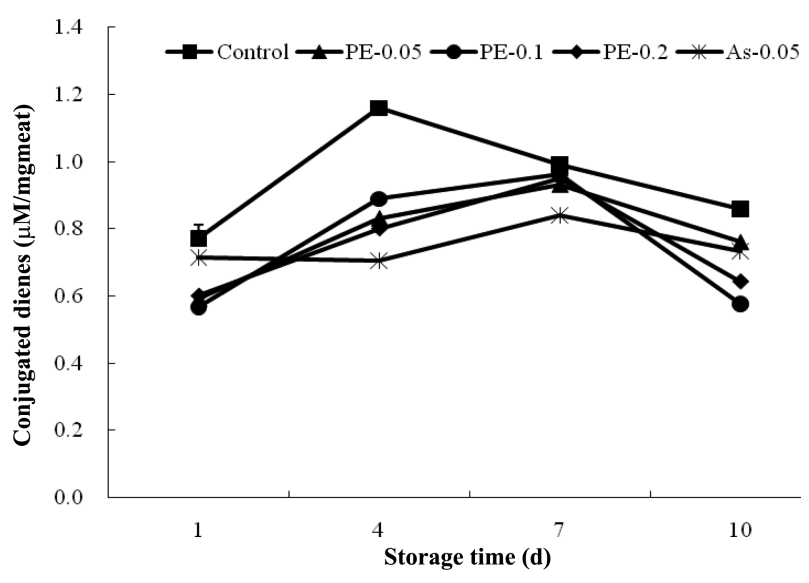

Fig. 1. Change in conjugated dienes $(\mu \mathrm{M} / \mathrm{mg}$ meat) of ground pork meat added ethanolic pumpkin leaf extracts (PE) during storage days.

addition of PE decreased the CD concentrations to levels lower than the control during the entire storage period. In particular, PE-0.1 and pE-0.2 had the lowest $(p<0.05) \mathrm{CD}$ concentration on day 10. Seo and Morr (1984) reported that antioxidant compounds like phenolics may lower CD concentrations. Furthermore, a previous study reported that pumpkin leaves have antioxidant activity (Cha, 2009).

Decomposition values of tri-glycerides and phospholipids, which are present in meat during storage, can be measured through free fatty acid (FFA) analysis (Dempster et al., 1985). The addition of PE delayed the formation of FFAs in ground pork during chilled storage, which ranged in concentration from 0.56 to $2.23 \%$ (Table 5). The samples containing PE had significantly lower $(p<0.05)$ FFA content compared to the control and AS0.05 treatment. Also, PE concentration had a significant $(p<0.05)$ effect on FFA content. Increases in FFA content were dependent on storage time for all treatments. A previous study found that the FFA percentage increased with increasing storage time (Lefebvre et al., 1994).

\section{Thiobarbituric acid reaction substances (TBARS) values}

Fig. 2 showed the TBARS values, which can be used as a measure of the concentrations of secondary lipid oxidation products such as aldehydes or ketones in samples containing PE (0.18-1.05 MDA mg/kg meat). Previously, a study found slightly higher TBARS levels (0.84-2.05 MDA $\mathrm{mg} / \mathrm{kg}$ ), in raw chicken patties during $13 \mathrm{~d}$ of storage at $4^{\circ} \mathrm{C}$. The TBARS values of the samples significantly increased $(p<0.05)$ with increasing storage time. Similar results were also observed in fresh minced beef, where the TBARS values increased with storage (up to 5 mg MDA $/ \mathrm{kg}$ sample) (Tang et al., 2006). The control in particular had the highest TBARS values during the 


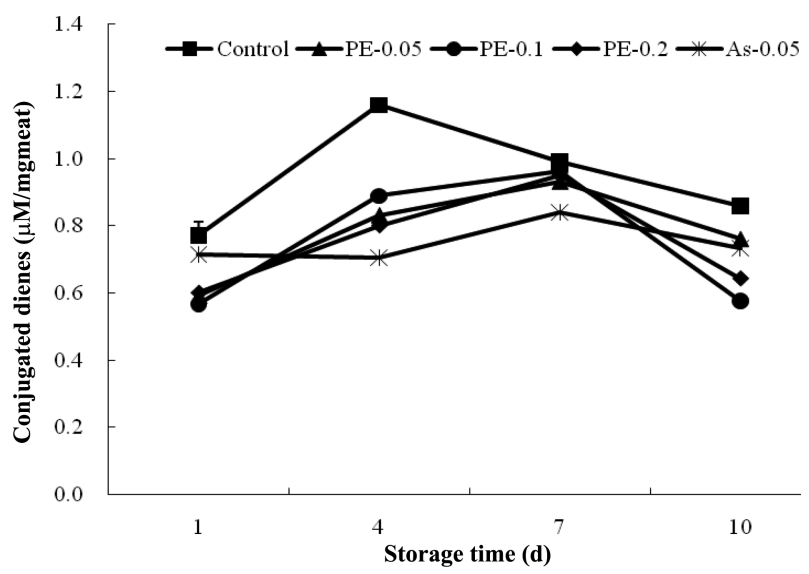

Fig. 1. Change in conjugated dienes ( $\mu \mathrm{M} / \mathrm{mg}$ meat) of ground pork meat added ethanolic pumpkin leaf extracts (PE) during storage days.

entire storage period. In the PE samples, the increase in TBARS values was slow and was lower $(p<0.05)$ level than in the Control. This result indicates that PE inhibited lipid oxidation in the meat samples due to the presence of phenolic compounds and antioxidant vitamins. Liu et al. (2009) reported decreased TBARS values in chicken sausage containing rosemary and Chinese mahogany relative to the control. Decreases in CDs concentration caused an increase in the production of secondary products such as TBARS during storage (Juntachote et al., 2007). The TBARS values of the $0.2 \%$ PE sample remained relatively constant during storage relative to As- 0.05 (Morris et al., 1950). This was most likely observed because this treatment contained the highest concentration of PE, and thus the highest amount of phenolic compounds. The TBARS value increased the most for the control and As0.05 samples due to the re-decomposition of peroxide between storage day 7 to 10 . Byun et al. (2001) also

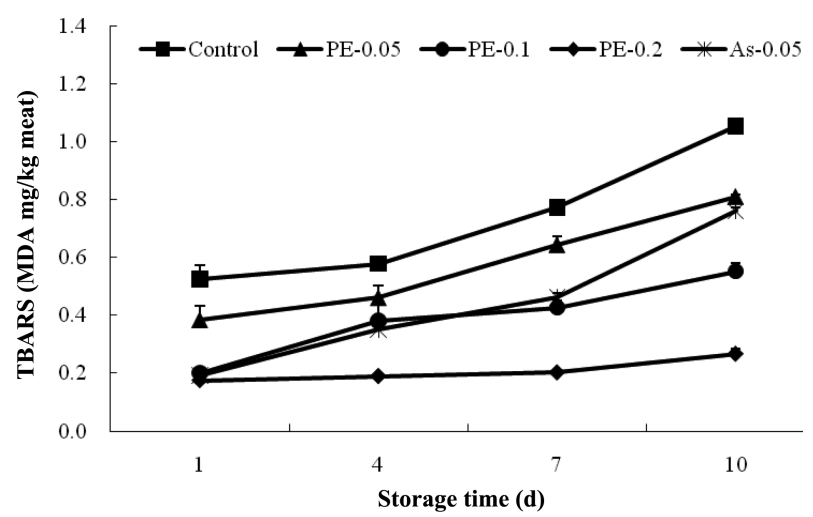

Fig. 2. Change in thiobarbituric acid reaction substance (TBARS) values (mg of MDA/kg meat) of ground pork meat added ethanolic pumpkin leaf extracts (PE) during storage days.
Table 5. Change in free fatty acid (FFA) (\%) of ground pork meat added ethanolic pumpkin leaf extracts (PE) during storage days

\begin{tabular}{lcccc}
\hline \hline \multirow{2}{*}{ Treatment $^{\mathrm{l})}$} & \multicolumn{4}{c}{ Storage periods (d) } \\
\cline { 2 - 5 } & 1 & 4 & 7 & 10 \\
\hline Control & $1.23 \pm 0.32^{\mathrm{Ac}}$ & $1.54 \pm 0.24^{\mathrm{Ab}}$ & $1.75 \pm 0.08^{\mathrm{Ab}}$ & $2.23 \pm 0.14^{\mathrm{Aa}}$ \\
PE-0.05 & $0.78 \pm 0.26^{\mathrm{Cb}}$ & $0.83 \pm 0.22^{\mathrm{Cb}}$ & $1.18 \pm 0.03^{\mathrm{Ca}}$ & $1.44 \pm 0.18^{\mathrm{Cb}}$ \\
$\mathrm{PE}-0.1$ & $0.62 \pm 0.12^{\mathrm{Dc}}$ & $0.84 \pm 0.16^{\mathrm{Cb}}$ & $1.12 \pm 0.25^{\mathrm{Cb}}$ & $1.25 \pm 0.06^{\mathrm{Da}}$ \\
PE-0.2 & $0.56 \pm 0.11^{\mathrm{Dc}}$ & $0.61 \pm 0.04^{\mathrm{Dc}}$ & $0.84 \pm 0.03^{\mathrm{Db}}$ & $0.96 \pm 0.52^{\mathrm{Ea}}$ \\
As-0.05 & $1.00 \pm 0.05^{\mathrm{Bc}}$ & $1.13 \pm 0.03^{\mathrm{Bc}}$ & $1.38 \pm 0.17^{\mathrm{Bb}}$ & $1.52 \pm 0.32^{\mathrm{Ba}}$ \\
\hline
\end{tabular}

All values are mean $\pm \mathrm{SD}$ of three replicates.

A-E Means within columns with different superscript letters are significantly different $(p<0.05)$.

${ }^{\mathrm{a}-\mathrm{c}}$ Means within rows with different superscript letters are significantly different $(p<0.05)$.

${ }^{1)}$ Control, minced pork without antioxidant powder; PE-0.05, minced pork meat with $0.05 \%$ pumpkin leaf extracts; PE-0.1, minced pork meat with $0.1 \%$ pumpkin leaf extracts; PE-0.2, minced pork meat with $0.2 \%$ pumpkin leaf extracts; As- 0.05 , minced pork meat with $0.05 \%$ ascorbic acid

observed sharp increases in TBARS values in pork after 8 $\mathrm{d}$ of storage.

\section{Acknowledgements}

This study was supported by the Ministry of Agriculture and Forestry (610002-03-2-SB120), Republic of Korea. The authors also partially supported by the Brain Korean 21 (BK 21) Project from Ministry of Education and Human Resources Development.

\section{References}

1. AOAC (2000) Official methods of analysis of AOAC. 16th ed, Association of Official Analytical Chemists, Washington, DC.

2. AOCS (1987) Official and tentative methods of the American Oil Chemist's Society. 3rd ed, Champaign, Il, USA.

3. Barlow, S. M. (1990) Toxicological aspects of antioxidants used as food additives. In: Food Antioxidants, Herdsen, B. J. F. (ed) Elsevier Applied Science, NY, p. 253.

4. Byun, P. H., Jung, J. H., Kim, W. J., and Yoon, S. K. (2001) Effects of garlic addition on lipid oxidation of ground pork during storage. Korean J. Food Sci. Ani. Resour. 17, 117122.

5. Cha, Y. Y. (2009). Experimental study on effects of Cucurbita moschata Duch. on antioxidation. J. Soc. Korean Med. Obes. Res. 9, 57-63.

6. Dempster, J. F., Hawrysh, Z. J., Shand, P., Lahola-Chomiak, L., and Corletto, L. (1985) Effect of low dose irradiation (radurisation) on the shelf life of beef burgers stored at $3^{\circ} \mathrm{C}$. Food Tech. 20, 145-154. 
7. Folch, J., Lee, M., and Stanley, S. G. H. (1957) A simple method for the isolation and purification of total lipids from animal tissues. J. Biol. Chem. 226, 497-509.

8. Fruhwirth, G. O., Wenzl, T., El-Toukhy, R., Wagner, F. S., and Hermetter, A. (2003) Fluorescence screening of antioxidant capacity in pumpkin seed oils and other natural oils. Eur. J. Lipid Sci. Tech. 105, 266-274.

9. Gharavi, N., Haggarty, S. E., and El-Kadi, A. O. (2007) Chemoprotective and carcinogenic effects of tert-butylhydroquinone and its metabolites. Curr. Drug Meta. 8, 1-7.

10. Glew, R. H., Glew, R. S., Chuang, L. T., Huang, Y. S., Millson, M., Constans, D., and Vanderjagt, D. T. (2006) Amino acid, mineral and fatty acid content of pumpkin seeds (Cucurbita spp.) and Cyperus esculentus nuts in the Republic of Niger. Plant Food Hum. Nutr. 61, 51-56.

11. Hinneburg, I., Dorman, H. J. D., and Hiltunen, R. (2006) Antioxidant activities of extracts from selected culinary herbs and spices. Food Chem. 97, 122-129.

12. Insausti, K., Beriain, M. J., Purroy, A., Alberti, P., Gorraiz, C., and Alzueta, M. J. (2001) Shelf life of beef from local Spanish cattle breeds stored under modified atmosphere. Meat Sci. 57, 273-281.

13. Jo, C., Son, J. H., Son, C. B., and Byun, M. W. (2003) Functional properties of raw and cooked pork patties with added irradiated, freeze-dried green tea leaf extract powder during storage at $4^{\circ} \mathrm{C}$. Meat Sci. 64, 13-17.

14. Juntachote, T., Berghofer, E., Siebenhandl, S., and Bauer, F. (2007) The effect of dried galangal powder and its ethanolic extracts on oxidative stability in cooked ground pork. LWTFood Sci. Tech. 40, 324-330.

15. Kulas, E. and Ackman, R. G. (2001) Different tocopherols and the relationship between two methods for determination of primary oxidation products in fish oil. J. Agr. Food Chem. 49, 1724-1729.

16. Kwon, Y.-I., Apostolidis, E., Kim, Y. C., and Shetty, K. (2007) Health benefits of traditional corn, beans, and pumpkin: In vitro studies for hyperglycemia and hypertension management. J. Med. Food 10, 266-275.

17. Ladikos, D. and Lougovois, V. (1990) Lipid oxidation in muscle foods: A review. Food Chem. 35, 295-314.

18. Lefebvre, N., Thibault, C., Charbonneau, R., and Piette, J. P. G. (1994) Improvement of shelf-life and wholesomeness of ground beef by irradiation, 2. Chemical analysis and sensory evaluation. Meat Sci. 36, 371-380.

19. Liu, D. C., Tsau, R. T., Lin, Y. C., Jan, S. S., and Tan, F. J. (2009) Effect of various levels of rosemary or Chinese mahogany on the quality of fresh chicken sausage during refrigerated storage. Food Chem. 117, 106-113.
20. Mc Carthy, T. L., Kerry, J. P., Kerry, J. F., Lynch, P. B., and Buckley, D. J. (2001) Assessment of the antioxidant potential of natural food and plant extracts in fresh and previously frozen pork patties. Meat Sci. 57, 177-184.

21. Morris, S. G., Myers, Jr., J. S., Kip, M. L., and Riemenschneider, R. W. (1950) Antioxidants in lard. J. Am. Oil Chem. Soc. 27, 105.

22. O'Grady, M. N., Monahan, F. J., and Brunton, N. (2001) Oxymyoglobin oxidation and lipid oxidation in bovine muscle - mechanistic studies. J. Food Sci. 66, 386-392.

23. Parry, J. W., Cheng, Z., Moore, J., and Yu, L. L. (2008) Fatty acid composition, antioxidant properties, and antiproliferative capacity of selected cold-pressed seed flours. J. Am. Oil Chem. Soc. 85, 457-464.

24. Peña-Ramos, E. A., and Xiong, Y. L. (2003) Whey and soy protein hydrolysates inhibit lipid oxidation in cooked pork patties. Meat Sci. 64, 259-263.

25. Prasetyo, M., Chia, M., Hughey, C., and Were, L. M. (2008) Utilization of electron beam irradiated almond skin powder as a natural antioxidant in ground top round beef. J. Food Sci. 73, 1-6.

26. SAS (2008) SAS/STAT Software for PC. Release 9.2, SAS Institute Inc., Cary, NC, USA.

27. Seo, A. and Morr, C. V. (1984) Improved high-performance liquid chromatographic analysis of phenolic acids and isoflavonoids from soybean protein products. J. Agr. Food Chem. 32, 530-533.

28. St. Angelo, A. J. (1996) Lipid oxidation in foods, Crit. Rev. Food Sci. Nutr. 36, 175.

29. Stevenson, D. G., Eller, F. J., Wang, L., Jane, J. L., Wang, T., and Inglett, G. E. (2007) Oil and tocopherol content and composition of pumpkin seed oil in 12 cultivars. J. Agr. Food Chem. 55, 4005-4013.

30. Tang, S. Z., Ou, S. Y., Huang, X. S., Li, W., Kerry, J. P., and Buckley, D. J. (2006) Effects of added tea catechins on colour stability and lipid oxidation in minced beef patties held under aerobic and modified atmospheric packaging conditions. J. Food Eng. 77, 248-253.

31. Tarladgis, B. G., Watts, B. M., and Younathan, M. T. (1960) A distillation method for the quantitative determination of malondialdehyde in rancid foods. J. Am. Oil Chem. Soc. 37, 44-48.

32. Xanthopoulou, M. N., Nomikos, T., Fragopoulou E., and Antonopoulou S. (2009) Antioxidant and lipoxygenase inhibitory activities of pumpkin seed extracts. Food Res. Intl. 42, 641-646.

(Received 2011.8.25/Revised 1st 2011.9.23, 2nd 2011.11.11/ Accepted 2011.11.22) 